\title{
Model Revitalisasi Mantra Monda'u Masyarakat Tolaki
}

\author{
${ }^{1}$ Nuryadin dan ${ }^{2}$ Ramlin \\ ${ }^{1}$ Universitas Lakidende Unaaha \\ ${ }^{2}$ Universitas Lakidende Unaaha \\ Correspondence email: nuryadinnuryadin@gmail.com
}

\begin{abstract}
Abstrak: Model revitalisasi pelaksanaan tradisi bercocok tanam padi di ladang masyarakat Tolaki yakni, monda'u. Monda'u adalah salah satu bentuk tradisi lisan dan sastra lisan yang belum memiliki dokumentasi secara tertulis. Masalah yang dibahas dalam penelitian ini adalah "Bagaimanakah model revitalisasi mantra tradisi monda'u dalam bercocok tanam padi ladang ketika mantra tidak di fungsikan lagi, dalam masyarakat Tolaki”. Penelitian ini bertujuan mengrevitalisasitradisi monda'udan mantra monda'u pada proses pelaksanaan bercocok tanam padi ladang masyarakat Tolaki secara umum. Manfaat dari penelitian ini adalah memberi sumbangsih kepada generasi muda saat ini agar mereka lebih banyak mengetahui tentang betapa pentingnya mempertahankan suatu budaya dan tradisi yang sudah sejak dulu dilakukan oleh nenek moyang kita. Penulis menggunakan metode etnografi, untuk mengungkapkan tradisi lisan yang berada di masyarakat lokal Konawe yang berhubungan dengan revitalisasi tradisi monda'u, revitalisasi pelaksanaan ritual, dan revitalisasi pewarisan mantra monda'u dengan menggunakan katakata atau tulis. Kemudian dalam penelitian ini penulis menggunakan beberapa konsep dan teori sebagai pendukung dalam tulisan ini, adapun konsep dan teorinya adalah: ritual, tradisi lisan, revitalisasi, pewarisan, dan formula.
\end{abstract}

Keywords: Revitalisasi, mantra, monda'u, masyarakat Tolaki.

\begin{abstract}
The revitalization model of the implementation of the tradition of rice cultivation in the fields of the Tolaki community, namely, monda'u. Monda'u is a form of oral tradition and oral literature that does not yet have written documentation. The problem discussed in this study is "How is the revitalization model of the monda'u traditional mantra in farming rice fields when the mantra is no longer functioning, in the Tolaki community". This study aims to revitalize the monda'ud tradition and the monda'u mantra in the process of implementing rice cultivation in the Tolaki community in general. The benefit of this research is that it contributes to today's young generation so that they know more about how important it is to maintain a culture and tradition that has been practiced by our ancestors for a long time. The author uses the ethnographic method, to reveal the oral traditions that exist in the local Konawe community related to the revitalization of the monda'u tradition, the revitalization of ritual implementation, and the revitalization of the inheritance of the monda'u mantra by using words or writing. Then in this study the author uses several concepts and theories as supporters in this paper, while the concepts and theories are: ritual, oral tradition, revitalization, inheritance, and formula.
\end{abstract}

Keywords: Revitalization, mantra, monda'u, Tolaki community.

\section{PENDAHULUAN}

Eksistensi atau kebertahanan sebuah kebudayaan sangat bergantung pada manusia atau masyarakat pendukungnya. Manusia ingin mempertahankan kebudayaannnya jika mereka menganggap kebudayaan itu masih memiliki kegunaan dan manfaat bagi masyarakat pendukungnya. Tradisi lisan, sebagai bagian dari kebudayaan, tidak terlepas dari peran manusia. Keinginan mempertahankan tradisi lisannya karena mereka menganggap tradisi lisan tersebut masih bermanfaat bagi kehidupan. Hal ini sesuai dengan apa yang dikatakan oleh Amir (1999:14) bahwa tradisi lisan tidak lepas dari fungsinya dalam kehidupan masyarakat.

Selanjutnya Sedyawati (1996:5) mengemukakan bahwa tradisi lisan adalah segala wacana yang disampaikan secara lisan, mengikuti cara atau adat-istiadat yang telah memola dalam suatu masyarakat. Lebih lanjut, Sedyawati dalam Anwar (1998:29) menegaskan bahwa penyampaian tradisi lisan itu ada yang sepenuhnya dengan menggunakan kata-kata, namun ada juga penggabungan dari kata-kata dan tindakan yang ada dalam tradisi lisan tersebut.

Seperti halnya daerah-daerah lain, Kabupaten Konawe, Konawe Selatan, salah satu kabupaten yang ada di Provinsi Sulawesi Tengggara memiliki berbagai tradisi lisan yang masih bertahan walaupun ada beberapa yang sudah hampir punah. Hal ini disebabkan kurangnya perhatian masyarakat pendukung budaya yang terutama genarasi muda. Sehingga dengan kondisi semacam ini ada tradisi-tradisi yang ada di masyarakat yang ditinggalkan atau tidak lagi menjadi bagian dari kehidupan mereka. Salah satu tradisi lisan yang keberadaannya sudah diambang kepunahan di Kabupaten Konawe adalah tradisi lisan monda'u. 
Nuryadin dan Ramli, Model Revitalisasi Mantra Monda'u Masyarakat Tolaki

Menurut Tarimana (1990:7), berdasarkan makna bahasa Tolaki,"monda'u dapat berarti bercocok tanam padi ladang yang berisikan mantra, ritual atau sindiran manusia dalam kehidupan sosialnya." Lebih lanjut, Tarimanamengatakan bahwa monda'u merupakan tradisi lisan masyarakat Tolaki dalam bercocok tanam padi ladang yang berisikan kegotong royongan dalam bertani pada ladang serta isi mantra monda' $u$ berisikan sindiran, yang bersifat kritik terhadap keadaan, pandangan, sifat, atau sikap seseorang/segolongan manusia. Selain itu, menurutnya, mantra monda'u dapat pula berarti ungkapan isi hati/perasaan yang mengandung permohonan atau menolak permohonan dan dapat juga merupakan suatu bantahan terhadap sindiran. Bila ditinjau dari segi isinya,mantra monda'u masyarakat Tolakimenurut Tarimana(1990:4) mempunyai beberapa tujuan, yaitu(1) mengkritik suatu perbuatan/sikap atau keadaan yang salah/keliru menurut norma agama serta tatacara dan tatakrama pergaulan; dengan demikian mengandung nilai pandidikan moral atau akhlak yang agamis; (2) permohonan yang diajukan secara sastrawi; (3) mengungkapkan secara sastrawi pengakuan atau kesediaan mengabulkan suatu permohonan; (4) mengungkapkan secara sastrawi aib orang lain; (5) mengungkapkan secara sastrawi bantahan atau balasan terhadap pantun dari orang lain atau pihak lawan.

Makna dan nilai yang terkandung dalam tuturan dalamritual mantra monda'u berisi nasehat yang bersifat edukatif yang sangat berguna dalam kehidupannya sehari-hari. Nasehat-nasehat tersebut berfungsi menyadarkan dan mengontrol orang-orang yang lagi berpergian jauhagar tidak melakukan atau meninggalkan sifatatau perangai yang paradoksal dan menyimpang dari norma-norma kesusilaan dan agama seperti yang dikemukakan oleh Tarimana di atas. Dengan demikian, sebuah tradisi lisan, termasuk monda'u, dipertahankan oleh masyarakat pemilik tradisi lisan karena kebermanfaatannya dalam kehidupan sehari-hari. Atau dengan kata lain, nilai dan fungsi ritual mantra monda'u tersebut masih dirasakan oleh masyarakat pemiliknya.

Perkembangan ilmu pengetahuan dan teknologi berdampak pada pergeseran tata nilai dan struktur budaya dalam masyarakat.Generasi muda Tolaki, sebagai bagian dari masyarakat, sudah tidak memperhatikan lagi kebudayaan-kebudayaan tradisional, termasuk ritual tradisi lisan monda'u. Arus informasi dan globalisasi telah berhasil menunjukkan dominasinya dengan merebut simpati dan perhatian masyarakat terutama generasi muda untuk meninggalkan tradisi. Hal ini berkonsekuensi pada terabaikannya tradisi-tradisi lisan kita yang merupakan warisan leluhur seperti makna mantra monda'u. Selain itu, karena penyebarannya bersifat lisan tanpa adanya dokumen tertulis dan penutur-penuturnya sudah semakin berkurang,ritual danmantra monda' $u$ ini akan terancam punah.

Sebagian besar masyarakat terutama generasi muda beranggapan bahwa makna mantra monda'u Tolaki merupakan pertunjukan yang sudah ketinggalan zaman. Anggapan seperti ini menyebabkanproses menanam padi ladang (monda'u) semakin jarang dilakukan lagi. Generasi muda lebih tertarik menonton acara-acara televisi yang serba mutakhir dan modern, menyaksikan konser-konser musik kontemporer, dan menghabiskan waktu mereka dengan bermain facebook.Atau singkatnya mereka lebih menyukai kebudayaan-kebudayaan modern atau global culture.Tontonan-tontonan yang sifatnya tradisi yang masih hidup ditengah-tengah masyarakat semakin kurang diminati.

Fenomena seperti ini telah menimbulkan keresahan dan kegelisahan bagi masyarakat terutama dari kalangan orang tua.Mereka khawatir tradisi lisan ini akan menjadi pupus dan hilang di tengah-tengah kehidupan mereka.Padahalmasyarakat pemilik tradisi ini terutama dari kalangan orang tua masih menginginkan kehadirantradisi lisan monda'u masyarakat Tolaki dalam kehidupan mereka. Hal ini disebabkanmasyarakat masih menganggap urgensi darinilai, makna, dan fungsimantra monda' ini dalam kehidupannya sehari-hari seperti yang terjadi pada waktu dulu.

Transformasi bertujuan agar monda' $u$ tersebut bisa berkontestasi dengan budaya-budaya global. Kontestasi yang dimaksudkan di sini bukan berarti sebuah perlombaan atau kompetisi mana yang bagus dan mana yang tidak bagus (antara budaya lokal dan budaya global atau antara petani lokal dan petani modern), namun bagaimana tradisi lisan monda'u sebagai kebudayaan lokal bisa hidup dan eksis kembali di tengahmaraknya kebudayaan global pada masa sekarang ini. Dengan demikian, makna dan nilai-nilai yang ada dalam mantra monda' $u$ tersebut bisa diinternalisasi dan diaplikasikan kembali dalam kehidupan mereka dalam menghadapi derasnya arus globalisasi dewasa ini. Akan tetapi, seperti apa bentuk transformasi yang 
Nuryadin dan Ramli, Model Revitalisasi Mantra Monda'u Masyarakat Tolaki

akan dilakukan sebagai model revitalisasi atau langkah dan upaya yang tepat untuk menggiatkan kembali tradisi lisan monda' $u$ pada masa sekarang yang sesuai dengan keinginan masyarakat Kabupaten Konawedan Konawe Selatanakan terjawab pada saat penelitian nanti.

Oleh karena itu, masyarakat Kabupaten Konawe dan KonaweSelatan sebagai pemilik tradisi lisan monda'uharus menemukan model revitalisasi yang tepat agar tradisi lisan monda' $u$ tersebut bisa menarik minat dan perhatian generasi muda sebagai pewaris tradisi ini sehingga bisa hidup kembali pada masa sekarang. Dengan adanya uraian dan pernyataan di atas, maka penulis, sebagai generasi muda yang sekaligus sebagai pendukung tradisi lisan monda'u ini, merasa tertarik untuk melakukan penelitian tentang revitalisasitradisi lisan monda' $u$ supaya bisa aktif kembali di daerah kabupaten Konawedan Konawe Selatan seperti pada waktu dulu.

\section{LANDASAN TEORI}

Vansina (1985:1) mendefinisikan tradisi lisan "the expression of "oral tradition" applies both to a process and to its product. The products are oral messages, at least a generation old. The process is the transmission of such messages by word of mouth over the time until the disappearance of the message" (ungkapan tradisi lisan ditinjau pada dua aspek, yaitu aspek proses dan produknya. Prosesnya adalah pewarisan pesan-pesan melalui mulut ke mulut sepanjang waktu sampai hilangnya pesan itu, sedangkan produknya adalah pesan-pesan lisan yang berdasarkan pada pesan dari generasi sebelumnya).

Menurut Keesing (1999:257), revitalisasi adalah perubahan komunitas karena kesadaran baru untuk mencapai cita-cita atau menempuh suatu cara hidup dengan sesuatu yang baru ataupun cara hidup dan nilainilai dari zaman yang sudah lampau. Keesing lebih menekankan pada kesadaran baru terhadap upaya-upaya perubahan kehidupan masyarakat yang sudah menyimpang dari tradisi-tradisi lama. Revitalisasi dapat berupa cara hidup yang sesuai dengan perkembangan zaman dengan tetap mengikuti aturan-aturan yang diwariskan oleh para leluhur ataupun tetap mengikuti pola kehidupan lama yang telah diturun-temurunkan dari suatu generasi ke generasi berikutnya.

Lord (2000:1) memberikan batasan tradisi lisan sebagai sesuatu yang dituturkan dalam masyarakat. Hal ini berarti bahwa unsur melisankan bagi penutur dan unsur mendengarkan bagi penerima menjadi kata kuncinya. Selanjutnya, Hoed (2008:184) mengatakan bahwa tradisi lisan adalah berbagai pengetahuan dan adat kebiasaan yang secara turun-temurun disampaikan secara lisan. Lebih lanjut, Hoed menyatakan bahwa tradisi lisan mencakup hal-hal seperti yang dikemukakan oleh Roger Tol dan Pudentia (1995:2), bahwa tradisi lisan tidak hanya mencakup cerita rakyat, mitos, legenda dan dongeng, tetapi juga mengandung berbagai hal yang menyangkut hidup dan kehidupan komunitas pemiliknya, misalnya kearifan lokal, sistem nilai, pengetahuan tradisional, sejarah, hukum adat, pengobatan, sistem kepercayaan dan religi, astrologi, dan berbagai hal seni.

\section{METODE}

Objek penelitianyang akan dikaji oleh peneliti dalam tulisan ini adalah revitalisasi tradisi lisan dalam Mantra Monda'u pada masyarakat Tolaki. Metode penelitian yang akan digunakan adalah metode penelitian kualitatif, sedangkan pendekatan yang akan digunakan adalah pendekatan etnografi. Penelitian kualitatif yang dimaksudkan di sini adalah penelitian yang digunakan untuk mengungkapkan gejala secara holistik-kontekstual melalui pengumpulan data dari latar alami dengan memanfaatkan diri peneliti sebagai instrumen kunci. Spradley (2007:3) mengatakan bahwa etnografi merupakan pekerjaan mendeskripsikan kebudayaan dengan tujuan utamanya adalah untuk memahami suatu pandangan hidup dari sudut pandang penduduk asli. Lebih lanjut, Spradley (2007:4) menegaskan bahwa etnografi tidak hanya mempelajari masyarakat, tetapi juga lebih dari itu etnografi belajar dari masyarakat.

Penulis akan menggunakan pendekatan etnografi karena penulis ingin mendapatkan gambaran nyata perwujudan mantra monda'udan pandangan masyarakat setempat (native's perspective) dalam hal ini masyarakat kabupaten Konawe dan Konawe Selatan sebagai pemilik kebudayaan ini tentang bagaimana model revitalisasi yang tepat terhadap tradisi lisan monda' $u$ tersebut. Penelitian ini akan diawali dengan melakukan studi kepustakaan untuk mendapatkan informasi tentang tradisi lisan monda'u yang ada di 


\section{Nuryadin dan Ramli, Model Revitalisasi Mantra Monda'u Masyarakat Tolaki}

Kabupaten Konawe dan KonaweSelatan atau yang berkaitan dengan objek penelitian ini. Selain itu, penulis juga akan melakukan wawancara yang diajukan secara lisan dengan daftar pertanyaan yang sudah disiapkan (terencana) maupun daftar pertanyaan yang tidak terencana. Pertanyaan-pertanyaan yang akan diajukan adalah relevan dengan model revitalisasi atau langkah dan upaya yang tepat terhadap revitalisasi tradisi lisan monda'u yang sesuai dengan keinginan masyarakat pemilik tradisi tersebut agar kembali dalam kehidupan mereka.

Wawancara akan dilakukan kepada para informan kunci, yaitu seniman atau petua. Berdasarkan pemahaman dan pengetahuan mereka tentang seluk-beluk perkembangan monda' $u$ termasuk alasan mengapa jarang dipertunjukkan dan bahkan hampir tidak dipentaskan lagi termasuk seperti apa model revitalisasi yang akan dilakukan.Selain itu, wawancara juga akan dilakukan kepada para pemangku adatkarena mereka mengetahui urgensi dan manfaat makna dan nilai yang terdapat dalam mantra monda'u.Pemilihan informan merujuk pada konsep Spradley (2007:69) yang pada prinsipnya menghendaki seorang informan itu harus paham terhadap budaya yang dibutuhkan.

Selainpetuadan pemangku adat, target wawanacara berikutnya adalah generasi muda.Mereka adalah pewaris tradisi baik masa kini maupun untuk masa yang akan datang. Dalam wawancara tersebut, penulis juga akan menanyakan kepada generasi muda tentang model revitalisasi atau langkah-langkah dan upayaupaya yang tepat terhadap mantra monda'u agar bisa aktif seperti duludi tengah maraknya budaya global. Wawancara yang akan dilakukan kepada generasi muda akan ditentukan dengan melihat ketokohannya yang dianggap mempunyai pandangan yang luas terhadap tradisi monda' $u$ dan mewakili generasi muda yang lain.

Model dan format wawancara akan disusun sedemikian rupa sesuai dengan kebutuhan penelitian. Mulai dari perlunya revitalisasi sampai pada langkah atau model revitalisasi dimaksud. Dengan demikian, penulis akan memperoleh informasi yang mendetail berdasarkan sudut pandang mereka tentang revitalisasi tradisi lisan monda'u pada masyarakat Kabupaten Konawe dan Konawe Selatan.

Akan tetapi, jika dirasa perlu, penelitiakan melibatkan diri dalam masyarakat tersebut dengan membentukforum diskusi tradisi lisan. tersebut akan dihadiri oleh tokoh masyarakat, pemangku adat, generasi muda,pemerintah setempat, dan peneliti sendiri untuk membicarakan tentang model revitalisasi yang akan dilakukan agar mantra monda'u tersebut bisa digiatkan atau digunakan lagi dalam proses bercocok tanam padi ladang masyarakat Tolaki yang bermukim di wilayah Konawe dan Konawe Selatan.Keterlibatan peneliti dalam forum ini adalah untuk memperoleh informasi model revitalisasi sesuai keinginan masyarakat pendukung tradisi.

Peneliti tidak bisa memaksakan model revitalisasi yang akan diajukan dalam forum tersebut untuk diterima, namun harus disesuaikan dengan keinginan masyarakat pemilik tradisi tersebut dan didiskusikan dengan para pemangku adat, tokoh masyarakat, dan generasi muda (perwakilannya), serta pemerintah setempat apakah model revitalisasi itu akan menjadi langkah dan upaya yang tepat untuk menggiatkan kembali tradisi monda' $u$ yakni bercocok tanam padi ladang pada masa sekarang ini.

Selanjutnya, pemerintah akan dilibatkan dalam forum tersebut karena upaya revitalisasi sebuah tradisi tidak terlepas dari kebijakan pemerintah. Hal ini berarti bahwa usaha revitalisasi tersebut akan jalan beriringan dengan kehendak masyarakat dan dukungan pemerintah.

\section{HASIL DAN PEMBAHASAN}

\section{Revitalisasi Kelisanan dalam Tradisi Monda'u}

Pada bagian awal tulisan ini sudah diuraikan bahwa tradisi lisan monda' $u$ merupakan salah satu tradisi perladangan bagi orang Tolaki di Konawe. Tradisi lisan monda'u tidak terlepas dari kelisanannya. Tanpa aspek kelisanan, sebuah tradisi tidak dapat dikatakan sebagai tradisi lisan. Menurut Ong (1989:49) bahwa pemikiran lisan bersifat situasional dan sangat akrab dengan alam manusia. Dalam konteks ini, mantra monda'u yang diucapkan oleh dukun kebun dapat bersifat situasional. Dengan demikian, mantra yang diciptakan dalam tradisi monda' $u$ bisa jadi merupakan respon terhadap lingkungan yang ada di sekitarnya, baik fenomena alam maupun fenomena sosial. Dapat dikatakan bahwa masyarakat Tolaki mengekspresikan pemikirannya melalui lantunan mantra yang berada dilingkungan orang Tolaki khusunya para petani ladang umumnya para tokoh adat dan dukun kampung. 


\section{Nuryadin dan Ramli, Model Revitalisasi Mantra Monda'u Masyarakat Tolaki}

Senada yang dikemukakan oleh Taslim (2010:48) adalah manusia yang selalu hidup akrab dengan semua makhluk (manusia dan lingkungan). Dalam hal ini alam dimaknai sebagai suatu komunitas sosial yang memiliki kelayakan untuk hidup. Interaksi antara sesama alam pun terjadi sehingga pemeliharaan terhadap alam menjadi tanggung jawab manusia. Dalam tradisi monda'u masyarakat Tolaki Konawe, dalam perwujudannya memberikan penghormatan terhadap leluhur-leluhur dan alam dalam bentuk upacara ritual dan salah satunya adalah upacara ritual mombotudu (awal penanaman benih padi), upacara mosehe (bersihbersih kampung)

Orang Tolaki dalam melaksanakan perladangan selalu melakukan upacara ritual dan membacakan mantra. Dalam pelaksanaan upacara ritual monda'u masyarakat Tolaki selalu mengundang pawang kebun yang mereka sebut to 'ono mombotudu. Dalam upacara ritual monda'u para petani ladang selalu menyiapkan beberapa materi perladangan yang bertujuan untuk kesakralan dalam proses perladangan.

Kembali pada pernyataan di atas bahwa tradisi lisan yang mengalami perubahan atau transformasi, aspek kelisanannya akan tetap inheren di dalamnya. Ibarat ketika kita akan membangun rumah, walaupun modifikasi bentuk apapun tetap akan memiliki fondasi. Seperti halnya dengan tradisi lisan monda'u walaupun mengalami perubahan dalam tahap-tahap prosesi perladangan, unsur kelisanannya tetap bermakna dan berfungsi bagi petani ladang yang sedang melaksanakan perladangan, serta kelisanan mantra monda' $u$ tetap ada dan tidak bisa dihilangkan. Dengan demikian kelisanan mantra monda' $u$ yang memiliki makna dan fungsi dalam proses perladangan merupakan kata kunci bagi petani ladang yang bermukim di Konawe.

Sebelum manusia mengenal tulisan (pra-aksara) maupun sudah mengenal aksara (tulisan), kelisanan itu selalu hadir dalam suatu tradisi yang berada di tengah-tengah masyarakat tradisional maupun modern, karena unsur kelisanan sangat penting bagi masyarakat dalam melakukan interaksi atau komunikasi dengan sesama.

Seorang to'ono mbotudu/osando (dukun kebun), sebelum melakukan ritual perladangan, terlebih dahulu mendiskusikan secara lisan kepada para petani yang akan melaksanakan proses perladangan agar mengetahui bagian-bagian tertentu yang harus disiapkan sebelum melaksanakan ritual, akan tetapi kadang dukun kebun selalu membuat catatan tertulis untuk petani agar kelisanan yang diucapkan oleh dukun dapat diingat dalam proses ritual berlangsung.

Fenomena seperti ini memberikan gambaran kepada kita bahwa ternyata unsur- unsur kelisanan pada masa sekarang yang ditandai dengan zaman tulisan dan dunia cetak serta kemajuan ilmu pengetahuan dan teknologi bukannya berkurang atau menjadi hilang. Sebaliknya, kelisanan itu semakin meningkat urgensinya di tengah-tengah masyarakat dewasa ini. Senada yang disampaikan oleh Ong (1982:9) bahwa dengan demikian tulisan sejak awal tidak mengurangi unsur kelisanan namun justru meningkatkan kelisanan itu sendiri, yang memungkinkan prinsip-prinsip atau konstituen-konstituen dalam berbicara menjadi sebuah seni yang ilmiah, sehingga sebuah penjelasan yang tersusun dan sistematis yang menunjukkan bagaimana dan mengapa tercapai seni berbicara yang baik serta dapat mencapai pengaruh-pengaruhnya yang spesifiknya yang bervariasi.

Monda' $u$ dikatakan sebagai tradisi lisan karena selain memiliki aspek kelisanan, juga memiliki unsur keberulangan atau pewarisan di dalamnya. Hal ini terlihat ketika dukun kebun dalam melakukan ritual selalu membacakan mantra monda'u secara berulang-ulang begitupun ketika dukun kebun mewariskan mantra kepada generasi berikutnya pola tersebut dilakukan berulang-ulang juga agar apa yang akan diwariskan dapat dipahami dan tidak mudah dilupakan oleh seorang penerima. Pembacaan mantra monda'u terdiri dari beberapa tahap, yaitu tahap pembuka dan tahap penutup. Berikut kelisanan ,fungsi dan makna mantra dalam tradisi upacara ritual monda'u.

\section{Revitalisasi Mantra Pembuka Lahan Perladangan}

Mantra monda' $u$ ini berisikan permintaan seorang dukun kebun untuk meminta izin kepada penguasa alam dan sekitarnya disini peneliti mengajak dukun kebun untuk mengulangi pembacaan mantra dalam proses pembukaan lahan monda'u. Berikut ini adalah mantra permulaan dalam prosesi perladangan yang biasa dibacakan oleh dukun kebun sebagai berikut;

Oh..oh..oh..oh..oh..oh..oh 
Nuryadin dan Ramli, Model Revitalisasi Mantra Monda'u Masyarakat Tolaki

Imbekoto inggoo, guruno uwuta, sangiaano wonua.

Weweungano wuta, karamano wonua

Tapuasano wuta, langgaino wonua

La limbai owuta, la limbai oleo, la limbai ohina, la limbai roroma

Ku onggo mosehe sinala, molisa sinerei, kenola sinal, kenola sinerei

Artinya: panggilan dimana kamu gerangan

Gurunya bumi, Dewanya negri, Saktinya bumi, Keramatnya negri

Penguasa bumi, laki-lakinya negri, yang selalu mengelilingi bumi

Yang menguasai matahari, yang menguasai malam

Kuakan mensucikan pelanggaran adat, menghilangkan dosa

Jika ada yang bersalah, jika ada yang berdosa.

Doa berikutnya.

Bismillahirrahmanirrahim

Metaabe ni'ino o kalo

Poawonggu hende-hende 'ikaa o'wuta

Nomeena ine wuta ari'anggu

Wuta auki menggura, maa keno menggura ni'ino puri pelenggu

Ikeni kupetungge karenggu, kupenggokoro I polawa naga

Kuperehu ine tanuno, keno eheakokaa membuleako, ki'oki kimbemadodo

Keno eheakokaa umianggomami, oleono ronga wingino

Artinya;

"Dengan nama Allah Yang Maha Pengasih dan Penyanyang

Permisi ini sebuah kalo, sifatku sama dengan tanah, karena dari tanah saya diciptakan

Tanah, engkau akan berumput, jika berumput ini telapak tanganku

DiSini saya menginjakkan kaki, saya berdiri di antara Naga, saya duduk di tanduknya

Semoga dia membalikkan badannya, sehingga kami tidak mendapat malapetaka

Semoga dia menjaga kami siang dan malam".

Mantra yang telah dipaparkan di atas diucapkan dengan suara lantang untuk menambah nilai dari mantra itu sendiri, hal ini senada dengan penyataan, Vansina (1973:34-83) yang mengatakan bahwa ungkapan yang berulang-ulang dapat menjadi pesan atau makna yang memiliki nilai sehingga pesan itu terungkap dalam nada dan suara serta bahasa tubuh yang dapat dipahami oleh masyarakat.

Pernyataan di atas memperlihatkan bahwa pelaksanaan upacara ritual monda'u, oleh dukun kebun selalu disertai dengan gerakan tubuh sehingga masyarakat Tolaki khususnya petani ladang dapat melihat betapa bermaknanya gerakan-gerakan yang dilakukan oleh dukun kebun. Tradisi monda'u merupakan tradisi lisan yang berbentuk ritual dan dilaksanakan secara turun temurun oleh masyarakat Tolaki pada waktu bercocok tanam padi ladang.

Fungsi tuturan di atas dapat dilihat dari sikap seorang hamba atau pawang kebun terhadap Tuhan, dengan mempersembahkan sebuah lingkaran rotan (kalo) agar pawang dan masyarakat yang akan melaksanakan prosesi perladangan mendapatkan perlindungan berupa keselamatan dalam membuka lahan perladangan agar tidak mendatangkan bahaya dan malapetaka. Kemudian tuturan pada bait kedua mengandung makna bahwa salah satu sifat manusia sama dengan tanah, karena manusia diciptakan dari tanah. Pawang kebun menegaskan bahwa dalam tubuh manusia terdapat sifat tanah, di mana manusia dan tanah adalah ciptaan yang Maha Kuasa. Sifat tanah yang dimaksud oleh dukun kebun adalah tanah mempunyai sifat sabar, demikian pula dengan manusia memiliki sifat sabar, artinya segala sesuatu yang dikerjakan harus selalu sabar.

Secara umum fungsi mantra di atas adalah osando/dukun sedang mengajak, memberitahu kepada semua penghuni area ini (makhluk gaib/jin) untuk datang berkumpul di area kebun. Makhluk halus dipanggil dukun untuk merokok, meminum dan makan sebagai imbalan atau balas budi terhadap penggunaan lahan yang diolah oleh manusia (petani) untuk bertani. Dengan disediakan makanan tersebut diharapkan makhluk gaib/ jin tidak mengganggu kebunnya para petani. Apabila para jin tetap mengganggu 
Nuryadin dan Ramli, Model Revitalisasi Mantra Monda'u Masyarakat Tolaki

kebun petani atau aktiviats para petani, maka mereka akan hancur lebur, binasa dan akan menjauh dari pemiliki kebun petani. Dan kalimat terakhir mantra tersebut yang berbunyi "kioki kimbemadodo, keno ehe'akokaa umianggomami ole'o rongaa wingino" artinya "kami tidak akan betah kalau kami tidak dijaga siang maupun malam", yang bermakna memberitahukan kepada seluruh makhluk halus baik yang tuli maupun yang normal pendengarannya, baik yang dekat keberadaannya maupun yang jauh keberadaannya dari kebun agar makhluk halus mematuhi perjanjian atau ajakan dari dukun (osando) untuk tidak mengganggu kebunnya para petani dan selalu menjaga mereka siang dan malam.

\section{Revitalisasi Mantra penghormatan pada Benih Padi (mantra mombotudu )}

Bismillahi rrahmani rahim

Kur...mangisi mbae (dewa padi), kur...wuraka mbae(dewi padi)

Ulukia minakia, peteliki wulaa, petumbala wulaa, inamu inawa wulaa

Amamu metoro wulaa, o'oketo mbuemu, ai tuduto I animo mami

\section{Artinya;}

Dengan nama Allah Yang Maha Pengasih dan Penyayang

kemarilah mangisi mbae(dewa padi), kemarilah wuraka mbae(dewi padi)

Jiwa semangatmu, kobarkan semangatmu, berisikan emas

Bertumpukan emas, indukmu mengalirkan emas, ayahmu bertumpukan emas

Panggillah anak cucumu agar kalian turun ke ladang kami

Adapun fungsi Tuturan tersebut, bahwa dukun kebun mengharapkan agar Allah Subbahanna Taalla memberikan perlindungan berupa keselamatan dalam melaksanakan penghormatan pada benih padi agar tidak mendatangkan kerugian. Kemudian tuturan mantra pada baris ke dua yakni, "mangisi mbae dan wuraka mbae" mengandung makna yakni, dukun kebun memanggil dewa padi dan dewi padi agar mendatangkan semangat sang padi yang akan tumbuh dengan baik dan subur. Serta tuturan wulaa bermakna agar tumbuhan padi nantinya dapat berisi dengan biji-biji beras yang mengkilap seperti emas. Dukun kebun juga berharap bahwa padi sangat berharga atau memiliki nilai kehidupan yang dapat mendatangkan manfaat bagi kehidupan sehari-hari, baik terhadap dukun kebun maupun kepada petani yang sedang melaksanakan perladangan. Kata "wulaa" yang berarti emas merupakan harta yang mempunyai nilai jual yang sangat tinggi, begitu pula nantinya biji-biji beras, pawang mengharapkan agar padi yang ditanam dapat membuahkan hasil yang berlimpah. Kemudian pawang mengharapkan kepada mangiisi mbae (dewa padi dan dewi padi) datang berkunjung ke ladang karena kegiatan menanam padi ladang akan dilaksanakan.

\section{Revitalisasi Mantra Menugal Padi (mantra motasu opae )}

Bismillahi rahmanir rahim

Inggomiu wakuni isi, inggomiu wakunda asi

Hende laa sumandu awu, hende laa kumeke one, pesukahakoto i'suere ndobu, Pesireakoto I'suere osu, pesukahakoto I'suere wuta, pesireakoto

I'suere wunua, Isaa leu mbebubuiti, leu meo'sopi

\section{Artinya;}

Dengan Nama Allah Yang Maha Kuasa dan Penyayang

Wahai mahluk halus perusak tanaman laki-laki

Wahai mahluk halus perusak tanaman perempuan

Engkau seperti lagi menimba abu, mudurlah engkau di lain lembah

Bergeserlah di lain gunung, dan mundurlah di daerah lain

Bergeserlah di alam lain, kamu dilarang datang mengambil dan mengisap tanaman kami.

Fungsi dari tuturan di atas adalah bahwa pawang mengharapkan kepada yang Maha Kuasa agar diberikan perlindungan dan keselamatan agar dalam melaksanakan prosesi perladangan tidak mendatangkan malapetaka atas dirinya beserta tanaman yang bakal di tanam. Kemudian bait kedua yang berbunyi wakuni asi dan wakunda asi, berarti makhluk halus yang berjenis kelamin laki-laki dan perempuan. Masyarakat Tolaki dan pawang kebun selalu berharap agar kedua makhluk itu tidak datang mengambil benih padi yang telah disiapkan untuk ditugal sehingga akan mencukupi bakal lahan yang akan ditanam, kemudian pawang juga berharap kepada makhluk halus tersebut ketika padi sudah mulai berbuah jangan isap isinya agar apa 
Nuryadin dan Ramli, Model Revitalisasi Mantra Monda'u Masyarakat Tolaki

yang diharapkan oleh petani ladang dapat dinikmati sampai musim berikutnya. Pawang meminta izin kepada kedua makhluk tersebut untuk pindah ke tempat lain atau alam lain.

\section{Revitalisasi Mantra Membuahkan Padi (mantra pombokombewua opae )}

Bismillahirahmanihrrahim

Kur...mangisi mbaeKur..wuraka mbae

Kopondoengako o'wulele

Aso'ndange wulele

Wulele Ali Fatimah

Pepotimburiakoto loso'ano oleo

Pepotimburiakoto tepuli'ano oleo

Totalampe ihana imoeri

Petakoto ine'mbuemu, au palikuku'I mbuemu

Pato hu, koa hu-huno

Artinya; Dengan menyebut nama Allah Yang Maha Pengasih dan Penyayang

Kemarilah dewa dan dewi padi

Kugantungkan kembang dan setangkai kembang, kembang Ali Fatimah

Bergantunglah pada anak cucumu, kau selimuti anak cucumu

Di empat sudut dan setiap sudut-sudutnya dapat kau selimuti.

Setiap mantra pasti memiliki fungsi yang sesuai dengan daerah masing-masing. Orang Tolaki dengan mantranya memiliki fungsi yang sangat erat hubungannya dengan kehidupan sosial masyarakat. Fungsi tuturan mantra di atas adalah bahwa dukun kebun/pawang meminta kepada Allah Yang Maha Kuasa serta kepada Dewa dan Dewi padi mereka turun diperladangan petani agar padi yang ditanam cepat berbunga dan berisikan padi yang baik. Adapun makna dari bait tuturan mantra monda'u di atas bahwa pawang/dukun kebun mengharapakan kepada dewa dan dewi padi berkunjung di ladang karena padi yang ditanam akan berbunga atau sudah berbunga, serta bunga padi menjulur ke berbagai arah; ke barat, ke timur, ke utara, dan ke selatan sehingga padi dapat berbunga dengan subur, serta nampak rimbun dan menutupi kelopak batang padi serta di setiap sudut-sudut areal perladangan, ini ditandai dengan kalimat "au palikukui'iki mbuemu"(selimuti anak cucumu).

\section{SIMPULAN}

Revitalisasi yang akan dilakukan terhadap tradisi lisan monda'u ini tidak berarti menghadirkan kembali bentuk tradisi ritual monda' $u$ seperti dulu. Namun, hal ini harus dilakukan semacam transformasi (perubahan-perubahan bentuk, genre, fungsi, dan sebagainya), agar menimbulkan daya tarik dari kalangan generasi muda untuk mempelajari jenis ritual dan mantra monda'u ini. Dengan demikian, nilai dan makna dari tradisi lisan monda' $u$ kembali diresapi oleh masyarakatnya atau akan menjadi bagian dari kehidupan. Hal ini didukung oleh hasil wawancara penulis dengan salah seorang tokoh masyarakat yang sering melakukan upacara ritual monda'u yang bernama Pandu pada penelitian pendahuluan. Wawancara ini dilakukan di Desa Lalowatu Kecamatan Angata dan Kecamatan Tinanggea, Kabupaten Konawe Selatan pada hari Kamis, tanggal 28 Juli 2019 yang lalu. Arsamid mengatakan "Agar mantra monda'u ini bisa aktif atau hidup kembali perlu dilakukan perubahan-perubahan. Supaya generasi muda bisa tertarik untuk mempelajari dan mengetahui bagaimana cara melakukan ritual monda'u. Sehingga makna, nilai, dan fungsinya bisa melekat dan dirasakan kembali oleh masyarakat".

\section{DAFTAR PUSTAKA}

Amir, Adriyeti. 1999. Studi Kasus Sastra Lisan Minangkabau. Warta ATL. Edisi kelima Juni.

Astra, I Gede Semadi. 2004. "Revitalisasi Kearifan Lokal Dalam Upaya Memperkokoh Jati Diri Bangsa"dalam I Wayan Ardika dan Darma Putra (ed). Politik Kebudayaan dan Identitas Etnik. Bali:Fakultas Satra Universitas Udayana dan Balimangsi Presss.

Bayu, Putra, Anwar. 1998. Tradisi Lisan Jeliheman. "Untuk Siapa dan Milik Siapa?" Warta ATL. Edisi keempat Mei. 
Nuryadin dan Ramli, Model Revitalisasi Mantra Monda'u Masyarakat Tolaki

Darwansari. 2011. Revitalisasi Tradisi Lisan Kantola Masyarakat Muna Sultra Pada Era Globalisasi. (tesis pascasarjana Universitas Udayana).

Endraswara, Suwardi. 2004. Tradisi Lisan Jawa. Yoyakarta: Narasi.

Hoed, B.H. 2008. Komunikasi Lisan sebagai Dasar Tradisi Lisan (dalam Metodologi Kajian Tradisi Lisan), Pudentia (editor). Jakarta:ATL.

Keesing, Roger M. 1999. Antropologi Budaya:Suatu Perspektif Kontemporer. (Samuel Gunawan Pentj). Jakarta:Erlangga.

Lord, Albert B. 2000. The Singer of Tales. New York: Atheneum.

1976. The Singer Resumes The Tales. London: Cornell University Press.

Pudentia, 2007. Hakikat Kelisanan dalam Tradisi Melayu Makyong. Depok: FIB Universitas Indonesia. ,(editor). 2008. Metodologi Kajian Tradisi Lisan. Jakarta: ATL.

Sarniati. 2011. Analisis Makna Ungkapan Kabhanti Modero Dalam Tradisi Masyarakat Muna. (Skripsi Fakultas Pendidikan dan Ilmu Keguruan Unhalu).

Sedyawati, Edi. 1996. "Kedudukan Tradisi Lisan dalam Ilmu-Ilmu Sosial dan Ilmu-Ilmu Budaya”, dalam warta ATL. Jurnal Pengetahuan dan Komunikasi Peneliti dan Pemerhati Tradisi Lisan. Edisi Maret. Jakarta:ATL.

Sibarani, Robert. 2004. Antropolinguistik: Antropologi Linguistik dan Linguistik Antropologi. Medan: Penerbit Poda.

Spradley, James P. 2007. Metode Etnografi. Yogyakarta: Tiara Wacana.

Sunarti, Sastri. 1999. Bailau Sastra Lisan Bayang Pesisir Selamatan Sumatera Barat. Tesis UI.

Tuloli, Nani. 1990. Tanggomo, Salah Satu Ragam Sastra Lisan Gorontalo. (Disertasi Fakultas Sastra UI). 1994. Penerapan Teori Dalam Penelitian Sastra Lisan. Makalah Penataran Sastra Nusantara

Tradisional Di Pekan Baru, tanggal 5 Januari. Tarimana, Abdurrauf. 1989. Kebudayaan Tolaki. Jakarta; Balai Pustaka. Perpustakaan FISIP Unhalu.

Tawolo dan Sarmadan. (2007) Jurnal Mombosuri Mbonda'u Masrakat Tolaki

Tamburaka, Rustam E. et.al.(2004). Sejarah Sulawesi Tenggara dan 40 Tahun Sultra Membangun. Jakarta :PT Inco.

Taslim, Noriah. 2010. Lisan dan Tulisan. Kuala Lumpur: Dewan Bahasa dan Pustaka.

Vansina, Jan. 1985. Oral Tradition As History. Great Britain:Heinemann Kenya. 